\title{
EFFECT OF OOCYTE QUALITY AND CUMULUS CELLS ON MEIOTIC COMPETENCE OF VITRIFIED-THAWED BUFFALO OOCYTES
}

\author{
EL-RHEEM, S.M.A ${ }^{1}$; KANDIL, O.M. ${ }^{2}$; EL-BAWAB, IMAN E. ${ }^{1}$; \\ METWELLY, K.K. ${ }^{1}$ and ABDOON, ASS ${ }^{2}$ \\ ${ }^{1}$ Theriogenology Department, Faculty of Veterinary Medicine, Alexandria University, Egypt. \\ ${ }^{2}$ Department of Animal Reproduction and Artificial Insemination, National Research Centre, Tahrir \\ Street, Dokki, 12622 Giza, Egypt.
}

Received: 30 March 2020; Accepted: 30 April 2020

\begin{abstract}
The work aimed to study the effect of oocytes quality and the presence or removal of cumulus cells on the meiotic competence of vitrified-thawed immature buffalo oocytes. In experiment 1, Immature buffalo oocytes were classified according to their quality ( group 1: excellent and good, group2: fair \& denuded) the groups were vitrified using 20\% Ethylen Glycol (EG) and $20 \%$ Dimethyle sulphoxide (DEMSO), then thawing after one week and in vitro matured in ISCOVE medium and kept at $38.5^{\circ} \mathrm{C}$ under $5 \% \mathrm{CO}_{2}$ for $22 \mathrm{~h}$. The two groups were compared with the control without vitrification (in-vitro matured oocytes). Experiment 2, excellent and good immature buffalo oocytes were divided into two groups, G1: oocytes with cumulus, G2: oocytes without cumulus then vitrified / thawed as experiment 1, for in vitro maturation assessment. In experiment 1, The excellent and good quality immature oocytes showed significant $(\mathrm{p}<0.05)$ higher in-vitro maturation rate after thawing than fair and denuded buffalo oocytes also vitrification led to loss of oocytes and abnormalities of buffalo oocytes compared to the control. In experiment 2 , the presence of cumulus cells was significantly higher in $(\mathrm{P}<0.05)$ survivability and maturation rate than the oocytes without cumulus cells. In conclusion, selection of excellent and good quality oocytes with cumulus cells improve post thawing development of vitrified immature buffalo oocytes.
\end{abstract}

Key words: Vitrification- buffalo oocytes- oocytes quality- cumulus cells

\section{INTRODUCTION}

Worldwide, there is a growing awareness of the importance of the buffalo (Bubalus bubalis), which participates in Egyptian economy, contributing milk, meat and draught power for the agriculture sector

Corresponding author: Kandil, O.M.

E-mail address: omaima_mk@yahoo.com

Present address: Department of Animal Reproduction and Artificial Insemination, National Research Centre, Tahrir Street, Dokki, 12622 Giza, Egypt.
(Zoheir et al., 2007). Buffaloes are reported to have low reproductive performance with inherent reproductive problems (Nandi et al., 2002). The poor reproductive ability of the buffalo has become the major impediment in multiplication and genetic improvement of this species.

Oocyte cryopreservation is a rapidly advancing technology in which a female oocytes are extracted, frozen and stored (oocyte bank). A large number of superior animals are being slaughtered daily in the 
slaughterhouses for meat. Cryopreservation of oocytes collected from the ovaries of such animals and their subsequent utilization for production of embryos and for transfer may provide an opportunity to replenish the valuable germplasm lost and the genetic improvement of the species (Wani et al., 2004). Cryopreservation of mammalian oocytes at the immature stage is essential when conditions for IVM are not present at the site of oocyte retrieval and the possibility of their storage, eliminating the need for an in vitro fertilization laboratory near to the sites of aspiration and optimizing the in vitro embryo production (Somfai et al., 2012). In addition, the same authors indicated that, this approach is believed to be advantageous by avoiding the damages of meiotic spindle, induction of parthenogenesis and zona hardening which may occur during cryopreservation of mature oocytes.

However, oocyte cryopreservation has some problems such as the formation of ice crystal, osmotic shock and ultra-structural damage, all of those lead to low survival and/or poor oocytes meiotic competence (Szurek et al., 2011). The success of oocyte cryopreservation depends on many factors which can be divided in two groups: technical factors, referring to different protocols, cryoprotectants (CPAs), and devices used, oocyte factors, referring to the oocytes quality, the presence of cumulus cells (CCs) or the developmental stage of the oocyte (mature or germinal vesicle) (Escribano et al., 2016).

The ability to identify good quality oocytes is important to undergo normal in-vitro maturation; fertilization and development to the blastocyst stage (Sianturi et al., 2002). The most used criteria to assess the quality of the bovine oocytes for IVM are cumulus investment morphology and the microscopic aspect of the nucleus (De Wit et al., 2000).
The presence of CCs was necessary for cytoplasmic and nuclear maturation of cattle (Zhang et al., 1995) and buffalo (Kandil et al., 1999) oocytes, CCs play an important role during fertilization (Chian et al., 1996). However, it has been hypothesized that CCs and glycoproteins slow the penetration and unequal intracellular distribution of the CPA so inadequate cell protection and the removal of CCs increases the meiotic promoting factor activity and accelerates the transition to metaphase stage and the redistribution of cortical granules (Zhou et al., 2010).

The aims of this work are to study 1) Effect of vitrification and oocytes quality on meiotic competence of vitrified-thawed immature buffalo oocytes. 2) Effect of presence or absence of cumulus cells on meiotic competence of vitrified immature buffalo oocytes.

\section{MATERIALS AND METHODS}

\section{1- Collection of ovaries:}

Ovaries were collected from El-Warak slaughter house - Cairo for one year. 108 Ovaries were transported through isothermal container containing warm normal saline solution at $37^{\circ} \mathrm{C}$ and transported to the laboratory within 2 to $3 \mathrm{hrs}$. At the laboratory, ovaries were washed once with $70 \%$ ethanol and three times with normal saline solution supplemented with $100 \mathrm{IU} / \mathrm{m} 1$ penicillin and $100 \mu \mathrm{g} / \mathrm{m} 1$ streptomycin at $37^{\circ} \mathrm{C}$.

\section{2- Cumulus oocytes complex aspiration and selection:}

The cumulus oocytes complex (COCs) were aspirated from follicles of 2-8 mm diameter using 18 gauge needle containing $1 \mathrm{~m} 1$ of aspiration medium $(5 \mathrm{ml}$ Phosphate buffer saline, $3 \mathrm{mg} / \mathrm{ml}$ bovine serum albumin and $50 \mu \mathrm{g} / \mathrm{m} 1$ gentamycin sulphate). The contents were placed into sterile Falcon tube and kept in water bath at $37^{\circ} \mathrm{C}$ for $15 \mathrm{~min}$., allowing oocytes to settle down. The sediment at the bottom of the 
plastic tube was aspirated and placed into Petri dish containing aspiration medium for searching oocytes under stereomicroscope at $90 \times$ (Olymbus company).

Experiment 1: Effect of vitrification and oocytes quality on meiotic competence of vitrified-thawed immature buffalo oocytes.

According to the number of CCs layers and ooplasm morphology, oocytes quality (COCs) was determined according to Kandil et al. (1999) into (i) excellent, included oocytes with five or more layers of complete CCs and evenly granulated dark ooplasm; (ii) good, included oocytes with 1-4 layers of CCs and evenly granulated dark ooplasm; (iii) fair, oocytes with CCs incompletely surrounding the oocytes and little granulation in ooplasm; (iv) denuded, oocytes without $\mathrm{CCs}$ and covered by zona pellucida (Fig.1). 262 oocytes divided to two groups: group 1: excellent and good oocytes VS group 2: fair and denuded oocytes. The vitrified-thawed groups were compared with control groups (without vitrification) through 6 replicates.

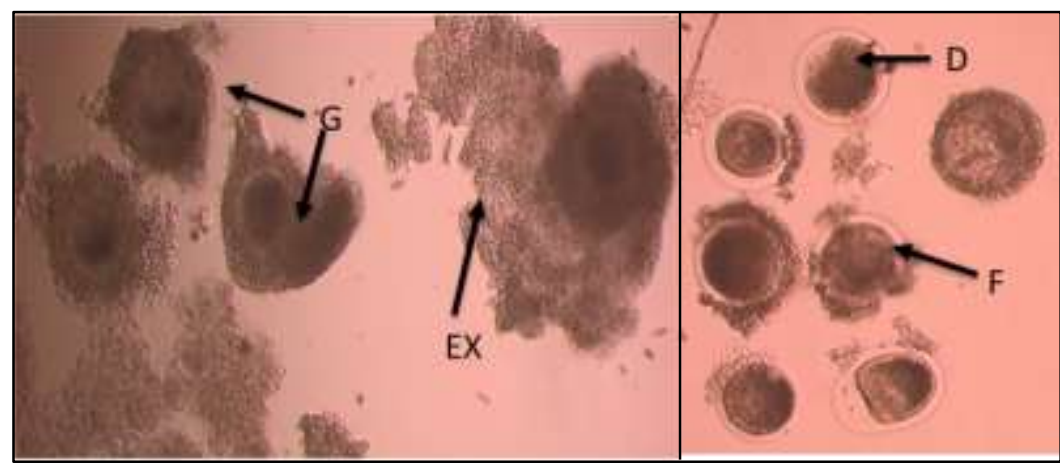

Fig. 1: Oocytes quality of buffalo

$\mathrm{Ex}=$ Excellent $\mathrm{G}=$ Good $\mathrm{F}=$ Fair $\mathrm{D}=$ denuded

Vitrification of immature oocytes group:

Immature oocytes were exposed to the vitrification solution in a two-step manner by equilibrating oocytes serially in vitrification solution VS1 $(10 \%$ EG $+10 \%$ DMSO and holding medium consisted of ISCOVE medium (Iscove et al., 1980), $10 \%$ FCS and $50 \mu \mathrm{g} / \mathrm{ml}$ gentamycin sulfate) for $1 \mathrm{~min}$ then vitrification solution VS2 $(0.35 \mathrm{~m}$ sucrose, $20 \% \mathrm{EG}+20 \% \mathrm{DMSO}$ in holding medium) (Gautam et al., 2008). Loading into $0.25 \mathrm{ml}$ French straw was done by using micro-classic pipette (Karl Hecht No. 558). First we draw loading medium column (Loading solution consisted of holding media $+0.5 \mathrm{~m}$ sucrose) which was separated from the oocytes in the vitrification solution 2 (VS2) by air bubble chamber from two sides then draw loading medium to the end of the straw. The loaded straw is sealed by polyvinyl powder and groups of approximately 25-30 oocytes were loaded into the straw. Loading of oocytes take one min from exposing them to VS2 till plunging into liquid nitrogen stored for one week (Gautam et al., 2008).

\section{Thawing of oocytes:}

For thawing, straws were plunged into a water bath at $37{ }^{\circ} \mathrm{C}$ for $10-15 \mathrm{~s}$. The vitrified-warmed oocytes were transferred immediately to fresh thawing medium (holding medium $+0.5 \mathrm{M}$ sucrose. A threestep procedure was used for dilution of sucrose gradually $(0.5,0.33$ and $0.17 \mathrm{M}$ sucrose each in holding medium, with 1 min equilibration in each solution). Oocytes were then washed several times with fresh maturation medium (Gautam et al., 2008).

\section{In vitro maturation of buffalo oocytes (vitrified-thawed groups or control groups):}

Oocytes were divided according to their quality and cultured in four well culture 
plates containing $500 \mu \mathrm{l}$ of maturation medium consisted of ISCOVE medium supplemented with $10 \%$ fetal (al)f serum (FCS), $10 \mu \mathrm{g} / \mathrm{m} 1$ FSH (Foltrob(A) V from Bioniche), $50 \mu \mathrm{g} / \mathrm{ml}$ gentamycin sulphate and $100 \mathrm{ng} / \mathrm{ml}$ Insulin like growth factor (IGF-1)) at $5 \% \quad \mathrm{CO}_{2}, 95 \%$ humidity at $38.5^{\circ} \mathrm{C}$ for $22 \mathrm{~h}$. according to $(5) \mu$ et al. (1999).

\section{Assessing of cumulus expansion of the oocytes:}

According to $\mathrm{CCs}$ expansion (exclude denuded cells) and judged into 4 grades (G0, GI, GII, GIII) (Kandil et al., 1999) Grade 0 (G0): with no expansion. Grade 1 (GI): with slight expansion in the outer layer of CCs. Grade 2 (GII): with moderate expansion. Grade 3 (GIII): with full expansion.

\section{Assessing of nuclear maturation of IVM oocytes:}

The presence of first polar body in the perivetteline space (MII) was the criteria for nuclear maturation of the oocytes. At the end of maturation period, oocytes were decomulated (the cumulus- cells were removed by repeated gentle pipetting using $100 \mu 1$ pipette) and confirmed by inverted microscope (Olympus Company).

Morphologically normal oocytes were fixed in $4 \%$ paraformaldehyde for staining with propidium iodide and image using confocal microscope (Zeiss LSM 710) for detection of stages of nuclear maturation.

\section{Morphological evaluation of vitrified- thawed immature buffalo oocytes:}

Oocytes were examined under an inverted microscope. The criteria used for assessing the post-thaw morphology of vitrified-thawed oocytes (Gautam et al., 2008) were as follows:

(1) Normal oocytes: with spherical, symmetrical shape and intact cumulus cells with homogenous cytoplasm were in-vitro matured.

Abnormal oocytes: with ruptured zona pellucida or ruptured vitelline membrane or fragmented cytoplasm with signs of degeneration.

Experiment 2: Effect of presence or removal of cumulus cells on meiotic competence of vitrification of immature buffalo oocytes

3. After aspiration and washing of 388 immature oocytes, excellent and good quality oocytes were selected and divided into two groups, oocytes with CCs group and oocytes were decomulated (removing cumulus cells by repeated gentle pipetting using $\quad 100 \quad \mu l$ pipette under stereomicroscope), then the two groups were vitrified, loaded, thawed, morphologically evaluated, in-vitro matured and nuclear maturation assessed as previously described in experiment 1 through 6 replicates.

\section{Statistical analysis: \\ Statistical analysis of the data}

Data were fed to the computer and analyzed using IBM SPSS software package version 20.0. (Armonk, NY: IBM Corp) Qualitative data were described using number and percent. Significance of the obtained results was judged at the 5\% level. The used test was Chi-square test For categorical variables, to compare between different groups

\section{RESULTS:}

Experiment 1: Effect of vitrification and oocyte quality on survivability and the meiotic competence of verified immature buffalo oocytes.

There was no significant difference $(\mathrm{P}<$ $0.05)$ between recovered immature oocytes after thawing (Table 1, Fig. 2) in excellent and good quality oocytes group (42.7\%) and fair and denuded quality oocytes group (57.3\%). The morphologically abnormal oocytes were significantly higher $(\mathrm{P}<0.05)$ in fair and denuded quality oocytes group $(69.9 \%)$ than excellent and good quality 
oocytes group (30.1\%) while the morphologically normal immature oocytes after thawing was significantly higher $(\mathrm{P}<$
$0.05)$ in excellent and good quality oocytes group $(73.3 \%)$ than fair and denuded quality oocytes group (26.7\%).

Table 1: Effect of oocytes quality on survivability of vitrified-thawed immature buffalo oocytes.

\begin{tabular}{cccccc}
\hline & Total & $\begin{array}{c}\text { Excellent and } \\
\text { good oocytes }\end{array}$ & $\begin{array}{c}\text { Fair and } \\
\text { denuded } \\
\text { oocytes }\end{array}$ & \multirow{2}{*}{$\chi^{\mathbf{2}}$} & p \\
\hline & No. (\%) & No. (\%) & No. (\%) & & \\
\hline No. of oocytes & $\mathbf{2 6 2}$ & $\mathbf{1 0 6}$ & $\mathbf{1 5 6}$ & --- & --- \\
\hline Recovered oocytes & $206(78.6)$ & $88 / 106(42.7)$ & $118 / \mathbf{1 5 6}(57.3)$ & 2.044 & 0.153 \\
\hline $\begin{array}{c}\text { Morphologically } \\
\text { abnormal oocytes }\end{array}$ & $146(70.9)$ & $44 / 88(30.1)$ & $102 / 118(69.9)$ & & \\
\cline { 1 - 3 } $\begin{array}{c}\text { Morphologically normal } \\
\text { oocytes }\end{array}$ & $60(29.1)$ & $44 / \mathbf{8 8}(73.3)$ & $16 / 118(26.7)$ & $32.427^{*}$ & $<0.001^{*}$ \\
\hline
\end{tabular}

$\chi^{2}$ : Chi square test

p: p value for comparing between Excellent and good oocytes group and Fair and denuded oocytes group

*: Statistically significant at $\mathrm{p} \leq 0.05$

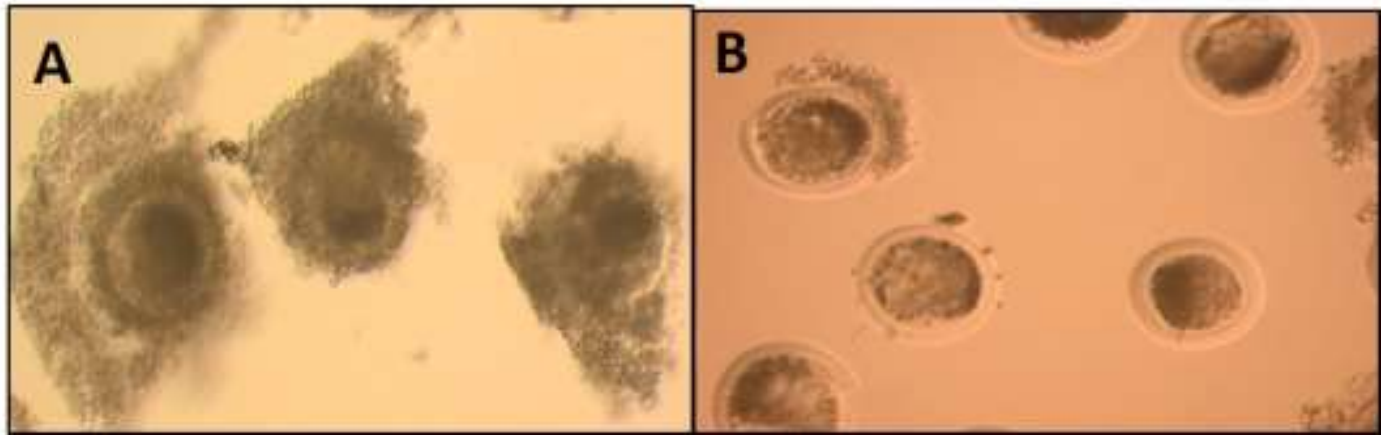

Fig. 2: Effect of oocytes quality on vitrified-thawed immature buffalo oocytes. $\mathrm{A}=$ Excellent and good oocytes, $\mathrm{B}=$ Fair and denuded oocytes

The effect of oocytes quality on abnormal morphological changes in vitrified-thawed immature oocytes (Table 2, Fig. 3), the vitrified /thawed immature buffalo oocytes showed morphological abnormality as zona crack, changes in shape and leakage. The percentage of oocytes that affected by zona crack or changes in shape or leakage showed no significant values $(\mathrm{P}<0.05)$ between excellent and good quality oocytes group $(34.5 \%, 26.7 \%$ and $27.6 \%$ respectively) and fair and denuded oocytes group $(65.5 \%, \quad 73.3 \%$ and $72.4 \%$ respectively).

Table 2: The effect of oocytes quality on abnormal morphological changes in vitrified-thawed immature oocytes.

\begin{tabular}{|c|c|c|c|}
\hline & $\begin{array}{l}\text { Excellent and good } \\
\text { oocytes }\end{array}$ & $\begin{array}{c}\text { Fair and denuded } \\
\text { oocytes }\end{array}$ & $\chi^{2}(\mathbf{p})$ \\
\hline & No. $(\%)$ & No. $(\%)$ & ---- \\
\hline Zona crack & $20 / 44(34.5)$ & $38 / \mathbf{1 0 2}(65.5)$ & $0.863(0.353)$ \\
\hline Changes in shape & $8 / 44(26.7)$ & $22 / \mathbf{1 0 2}(73.3)$ & $0.216(0.642)$ \\
\hline Leakage & $16 / 44(27.6)$ & $42 / \mathbf{1 0 2}(72.4)$ & $0.297(0.586)$ \\
\hline No. of oocytes & 44/88 (30.1) & 102/118 (69.9) & $32.427^{*}\left(<0.001^{*}\right)$ \\
\hline
\end{tabular}




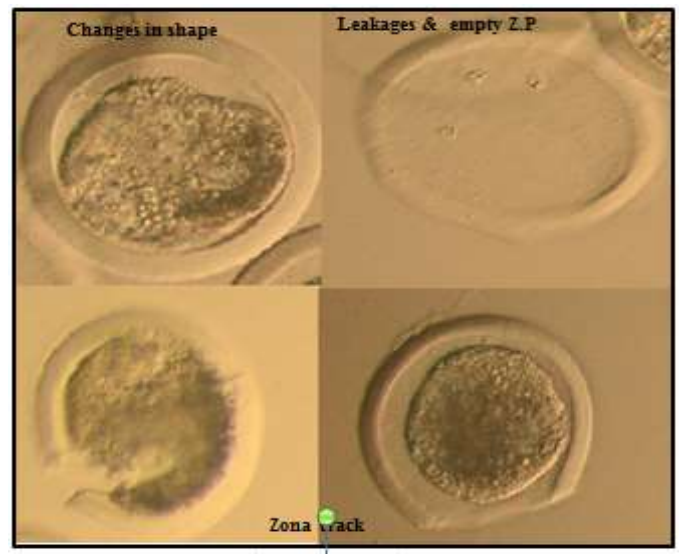

Fig. 3: Abnormal morphological changes in vitrified-thawed immature oocytes in buffalo (changes in shape, leakage and zona crack).

The cytoplasmic maturation of the control group and vitrified buffalo oocytes (Table 3, Fig. 4) showed that excellent and good quality oocytes was significantly high $(\mathrm{P}<0.05)$ in GIII and GII expansion of control group (49.53\%, 33.6\% respectively) when compared with other groups. While vitrified-thawed fair oocytes was significant high in GI and G0 $(37.5 \%, 50.0 \%$ respectively) than other groups.

Table 3: The effect of vitrification and oocytes quality on cytoplasmic maturation of buffalo oocytes.

\begin{tabular}{|c|c|c|c|c|c|c|}
\hline & \multicolumn{2}{|c|}{ Vitrified-thawed } & \multicolumn{2}{|c|}{ Control } & \multirow[b]{2}{*}{$\chi^{2}$} & \multirow[b]{2}{*}{${ }^{\mathrm{MC}} \mathbf{p}$} \\
\hline & $\begin{array}{l}\text { Excellent \& } \\
\text { good oocytes }\end{array}$ & Fair oocytes & $\begin{array}{l}\text { Excellent \& } \\
\text { good oocytes }\end{array}$ & Fair oocytes & & \\
\hline & No. $(\%)$ & No. (\%) & No. $(\%)$ & No. (\%) & \multirow{6}{*}{$90.449^{*}$} & \multirow{6}{*}{$<0.001^{*}$} \\
\hline GIII & $12(27.3)$ & $0(0.0)$ & $53(49.5)$ & $5(7.9)$ & & \\
\hline GII & $14(31.8)$ & $2(12.5)$ & $36(33.6)$ & $9(14.3)$ & & \\
\hline GI & $8(18.2)$ & $6(37.5)$ & $15(14.0)$ & $22(34.9)$ & & \\
\hline G0 & $10(22.7)$ & $8(50.0)$ & $3(2.8)$ & $27(42.9)$ & & \\
\hline $\begin{array}{l}\text { Total No. } \\
\text { of oocytes }\end{array}$ & 44/88 (19.1) & $16 / 118(7.0)$ & $107 / \mathbf{1 7 0}(46.5)$ & $63 / 170(27.4)$ & & \\
\hline
\end{tabular}

$\chi^{2}$ : Chi square test MC: Monte Carlo

$\mathrm{p}$ : $\mathrm{p}$ value for comparing between vitrified and thawed groups and control groups

*: Statistically significant at $\mathrm{p} \leq 0.05$

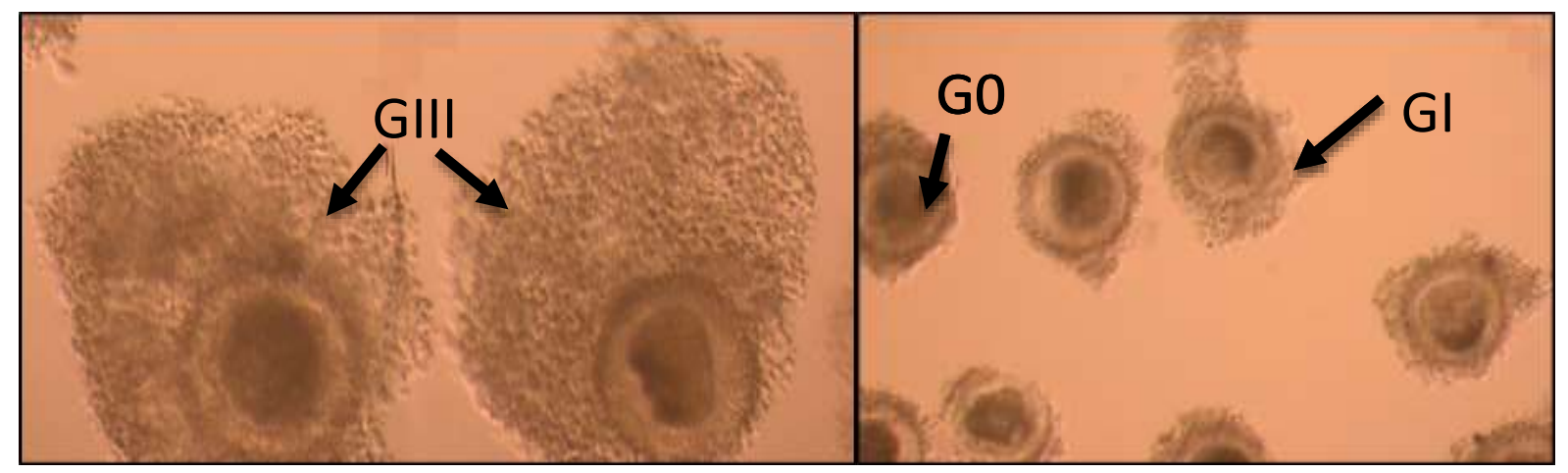

Fig. 4: The effect of oocytes quality on cytoplasmic maturation of vitrified- thawed immature buffalo oocytes (200x) 
Nuclear maturation (MII) of the control group and vitrified buffalo oocytes (Table 4, Fig. 5) showed that, the percentage of mature oocytes with $1^{\text {st }}$ polar body was significantly higher $(\mathrm{P}<0.05)$ in excellent and good quality oocytes of control group (75.7\%) when compared with excellent and good vitrified-thawed oocytes group $(31.8 \%)$ and fair and denuded control group $(27.7 \%)$.

Table 4: Effect of vitrification and oocytes quality on nuclear maturation of buffalo oocytes.

\begin{tabular}{|c|c|c|c|c|c|c|}
\hline & \multicolumn{2}{|c|}{ Vitrified-thawed oocytes } & \multicolumn{2}{|c|}{ Control } & \multirow[b]{2}{*}{$\chi^{2}$} & \multirow[b]{2}{*}{${ }^{{ }^{M C}} \mathbf{p}$} \\
\hline & $\begin{array}{l}\text { Excellent } \\
\text { \& good } \\
\text { oocytes }\end{array}$ & $\begin{array}{c}\text { Fair\& } \\
\text { denuded } \\
\text { oocytes }\end{array}$ & $\begin{array}{c}\text { Excellent } \\
\text { \& good } \\
\text { oocytes }\end{array}$ & $\begin{array}{c}\text { Fair \& } \\
\text { denuded } \\
\text { oocytes }\end{array}$ & & \\
\hline & No. $(\%)$ & No. $(\%)$ & No. $(\%)$ & No. $(\%)$ & \multirow{5}{*}{$94.066^{*}$} & \multirow{5}{*}{$<0.001^{*}$} \\
\hline $\mathbf{1}^{\text {st }} \mathbf{P B}$ & $14(31.8)$ & $0(0.0)$ & $81(75.7)$ & $23(27.7)$ & & \\
\hline Without PB & $28(63.6)$ & $10(62.5)$ & $17(15.9)$ & $26(31.3)$ & & \\
\hline Degenerated & $2(4.5)$ & $6(37.5)$ & $9(8.4)$ & $34(41.0)$ & & \\
\hline $\begin{array}{c}\text { Total no. of } \\
\text { oocytes }\end{array}$ & $\begin{array}{l}44 / 88 \\
(17.6)\end{array}$ & $16 / 118(6.4)$ & $\begin{array}{c}107 / \mathbf{1 9 0} \\
(42.8)\end{array}$ & $\begin{array}{c}83 / \mathbf{1 9 0} \\
(33.2)\end{array}$ & & \\
\hline
\end{tabular}

$\chi^{2}$ : Chi square test MC: Monte Carlo

$\mathrm{p}$ : $\mathrm{p}$ value for comparing between vitrified and thawed groups and control groups

*: Statistically significant at $\mathrm{p} \leq 0.05$
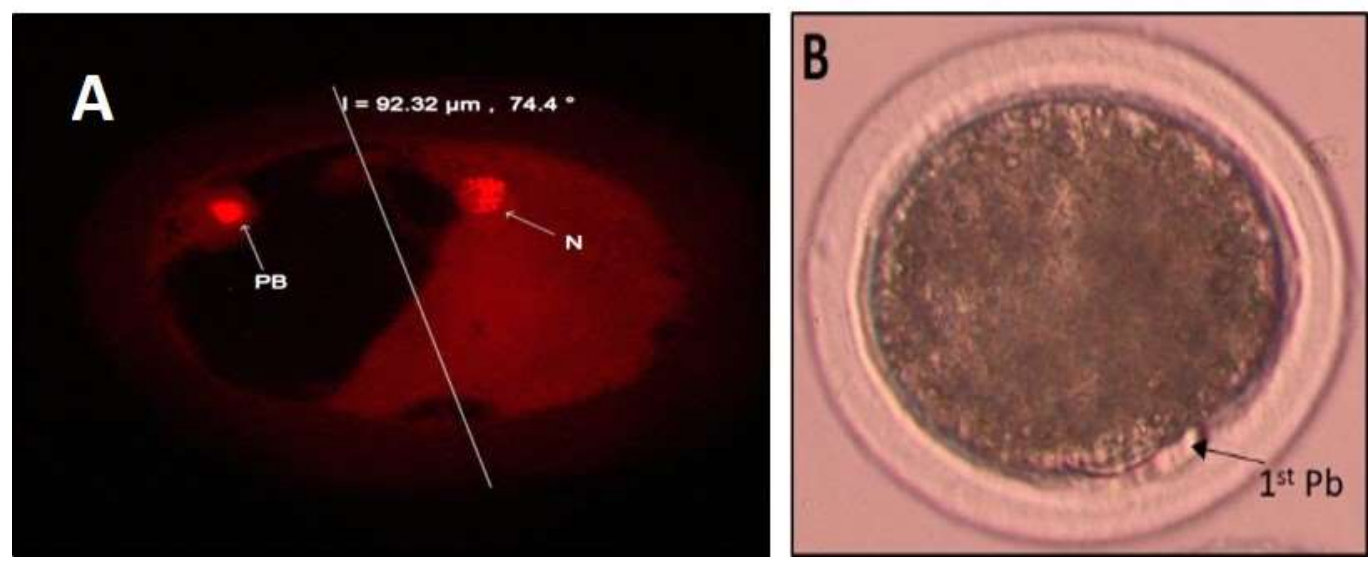

Fig. 5: In vitro maturation of vitrified-thawed immature buffalo oocytes showing $1^{\text {st }} \mathrm{PB}$ (MII) using confocal (A) 400X and inverted microscope $200 \mathrm{X}$.(B) $1^{\text {st }} \mathrm{PB}=1^{\text {st }}$ polar body, $\mathrm{N}=$ nucleus. The diminution of matured buffalo oocytes use in confocal microscope 63 lens $=92.32 \mathrm{um}$.

The percentages of nuclear maturation of the vitrified-thawed oocytes groups were recorded (Table 5, Fig. 6-7), fair and denuded quality oocytes group showed higher percentage $(\mathrm{P}<0.05)$ in germinal vesicle state $(66.7 \%)$ than excellent and good quality oocytes group (33.3\%). The percentages of oocytes with germinal vesicle breakdown, metaphase I and metaphase II in excellent and good quality oocytes group was significantly $(\mathrm{P}<0.05)$ higher $\quad(9.09 \%, \quad 22.72 \%, \quad 31.81 \%$ respectively) than fair and denuded quality oocytes group. 
Table 5: The effect of oocytes quality on nuclear maturation stages of vitrified-thawed buffalo oocytes.

\begin{tabular}{|c|c|c|c|c|}
\hline & $\begin{array}{c}\text { Excellent \& good } \\
\text { oocytes }\end{array}$ & $\begin{array}{c}\text { Fair \& denuded } \\
\text { oocytes }\end{array}$ & $\chi^{2}$ & ${ }^{F E} \mathbf{p}$ \\
\hline & No. $(\%)$ & No. $(\%)$ & & \\
\hline No. of oocytes & $44 / 88$ & $16 / \mathbf{1 1 8}$ & & \\
\hline Matured oocytes $1^{\text {st }} \mathbf{P B}$ & $14 / 44(100.0)$ & $0 / \mathbf{1 6}(0.0)$ & $6.640^{*}$ & $0.013^{*}$ \\
\hline GV & $2 / 44(33.3)$ & $4 / 16(66.7)$ & $5.455^{*}$ & $0.038^{*}$ \\
\hline GVBD & $4 / 44(100.0)$ & $0 / \mathbf{1 6}(0.0)$ & 1.558 & 0.565 \\
\hline M-1 & $10 / 44(100.0)$ & $0 / 16(0.0)$ & $4.364^{*}$ & $0.049^{*}$ \\
\hline Leakage & $12 / 44(66.7)$ & 6/16(33.3) & 0.584 & 0.529 \\
\hline Degenerated & $2 / 44(25.0)$ & $6 / 16(75.0)$ & $11.027^{*}$ & $0.003^{*}$ \\
\hline
\end{tabular}

$\mathrm{GV}=$ germinal vesicle, $\mathrm{GVBD}=$ germinal vesicle breakdown, $\mathrm{M}-\mathrm{I}=$ meiosis $\mathrm{I}$.

$\chi^{2}$ : Chi square test FE: Fisher Exact

$\mathrm{p}$ : $\mathrm{p}$ value for comparing between excellent and good oocytes and fair and denuded oocytes

*: Statistically significant at $\mathrm{p} \leq 0.05$

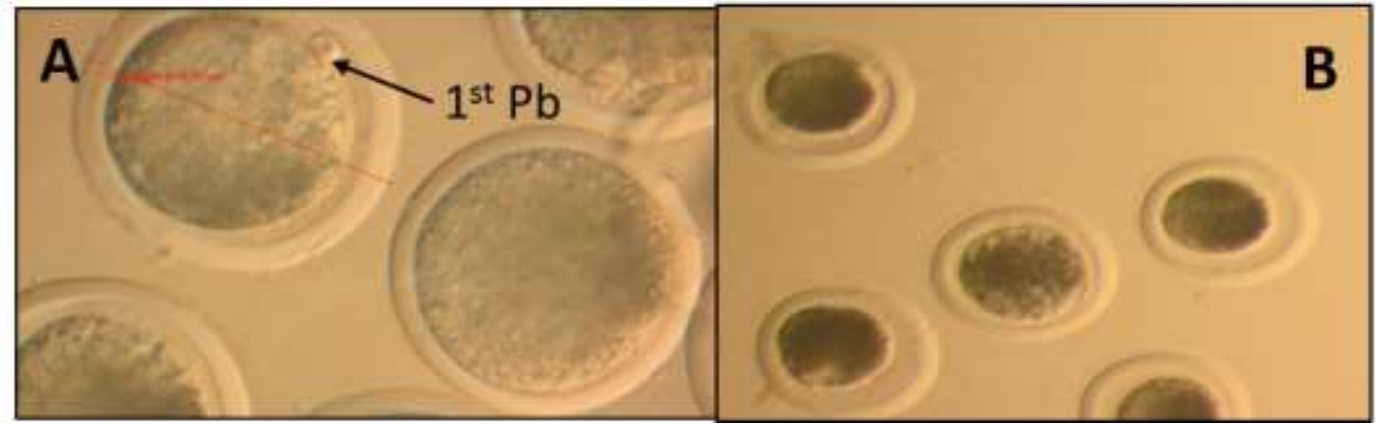

Fig. 6: Effect of oocytes quality on nuclear maturation of in vitro matured vitrified-thawed immature buffalo oocytes $\mathrm{A}=$ excellent and good oocytes matured with $1^{\text {st }}$ polar body $\left(1^{\text {st }} \mathrm{PB}\right)$, $\mathrm{B}=$ fair and denuded oocytes

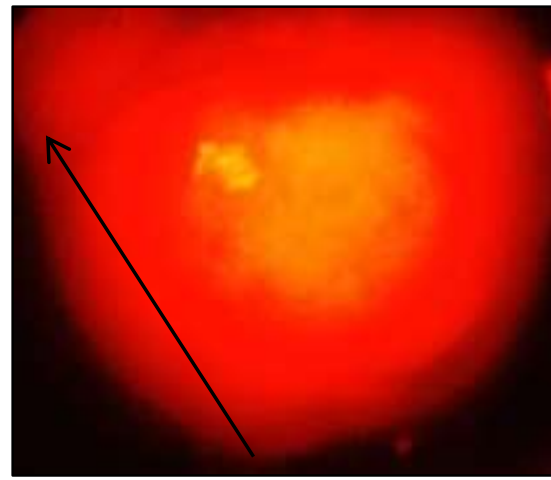

GVBD

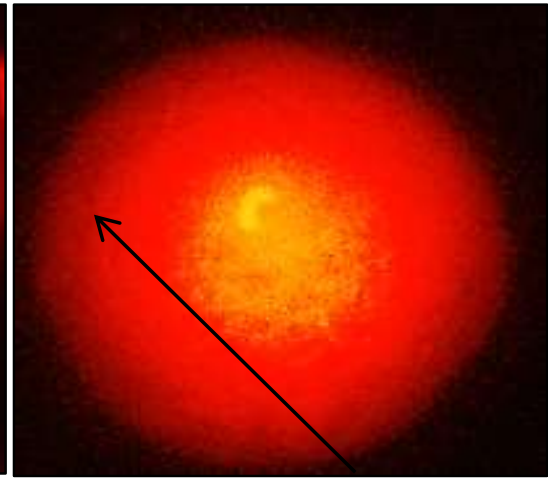

MI

Image 7: Oocytes stained by PI showing GVBD and MI (Fluorescent inverted microscope 200X)

Experiment 2: Effect of cumulus cells (CCs) on meiotic competence of vitrifiedthawed immature oocytes

There wasn't significant difference $(\mathrm{P}<0.05)$ of recovered oocytes (Table 6, Fig. 8) after thawing between immature oocytes with CCs group $(51.8 \%)$ and immature oocytes without CCs group $(48.1 \%)$. The percentage of morphologically abnormal oocytes were significantly higher $(\mathrm{P}<0.05)$ in immature oocytes without CCs group (64.8\%) than immature oocytes with CCs group (35.2\%). However, morphologically normal oocytes showed higher significant values $(\mathrm{P}<0.05)$ in immature oocytes with CCs group (83.6\%) than immature oocytes without CCs group $(16.4 \%)$. 
Table 6: The effect of CCs on survivability of vitrified-thawed immature oocytes.

\begin{tabular}{ccccccc}
\hline & Total & $\begin{array}{c}\text { Oocytes with } \\
\text { CCs }\end{array}$ & $\begin{array}{c}\text { Oocytes } \\
\text { without CCs }\end{array}$ & \multirow{2}{*}{$\chi^{2}$} & \multirow{2}{*}{ p } \\
\cline { 1 - 4 } & No. $(\%)$ & No. $(\%)$ & No. $(\%)$ & & & \\
\hline No. of frozen oocytes & $\mathbf{3 8 8}$ & $\mathbf{1 9 0}$ & $\mathbf{1 9 8}$ & & \\
\hline No. of recovered oocytes & $320(82.5)$ & $166 / \mathbf{1 9 0}(51.9)$ & $154 / \mathbf{1 9 8}(48.1)$ & $6.170^{*}$ & $0.013^{*}$ \\
\hline No. of morph. abnormal & $210(65.6)$ & $74 / \mathbf{1 6 6}(35.2)$ & $136 / \mathbf{1 5 4}(64.8)$ & $67.732^{*}$ & $<0.001^{*}$ \\
\hline No. of morph. normal & $110(36.4)$ & $92 / \mathbf{1 6 6}(83.6)$ & $18 / \mathbf{1 3 6}(16.4)$ & $57.452^{*}$ & $<0.001^{*}$ \\
\hline
\end{tabular}

$\chi^{2}$ : Chi square test

p: $p$ value for comparing between oocytes with CCs and oocytes without CCs

*: Statistically significant at $\mathrm{p} \leq 0.05$

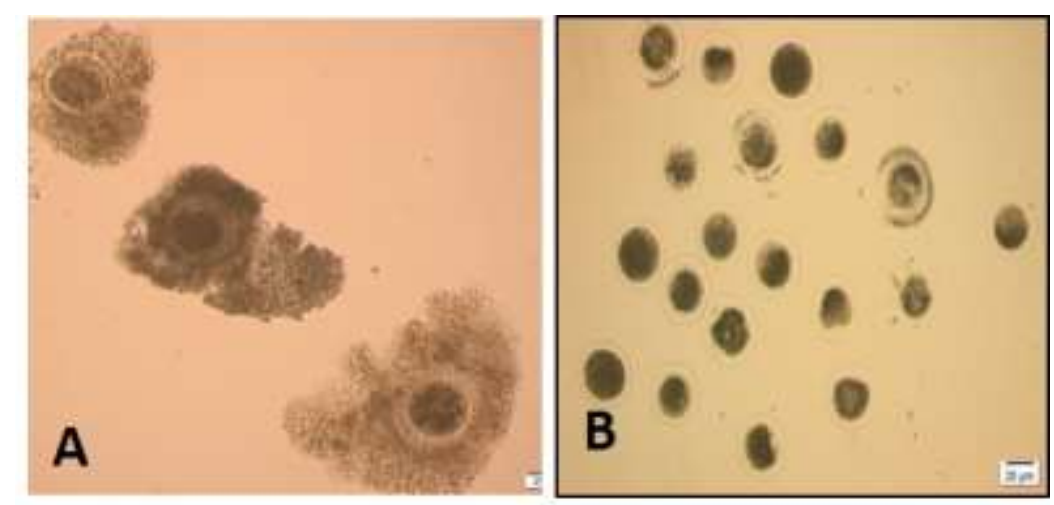

Fig. 8: Vitrified-thawed immature buffalo oocytes with CCS (A) and without CCs (B) inverted microscope $(90 \mathrm{X})$

The effect of $\mathrm{CCs}$ on the morphological appearance of vitrified thawed immature oocytes (Table 7) showed that the percentage of oocytes that affected by zona crack was not significantly $(\mathrm{P}<0.05)$ different between immature oocytes with CCs group $(40.2 \%)$ and immature oocytes without CCs group (59.8\%). The change in shape in vitrified - thawed immature oocytes showed higher significant $(\mathrm{P}<0.05)$ values in immature oocytes without CCs group $(77.8 \%)$ than immature oocytes with CCS group (22.2\%). The percentages of leakage oocytes was significantly higher $(\mathrm{P}<0.05)$ in oocytes with CCs $(57.6 \%)$ when compared with oocytes without CCs $(42.4 \%)$.

Table 7: The effect of CCs on the abnormal morphological changes in vitrified-thawed immature buffalo oocytes.

\begin{tabular}{cccc}
\hline & \multirow{2}{*}{ Oocytes with CCs } & $\begin{array}{c}\text { Oocytes without } \\
\text { CCs }\end{array}$ & \multirow{2}{*}{$\chi^{\mathbf{2}(\mathbf{p})}$} \\
\cline { 2 - 4 } & No. $(\boldsymbol{\%})$ & $\mathbf{N o .}(\boldsymbol{\%})$ & \\
\hline Zona crack & $35 / 74(40.2)$ & $52 / \mathbf{1 3 6}(59.8)$ & $1.622(0.203)$ \\
\hline Changes in shape & $20 / 74(22.2)$ & $70 / \mathbf{1 3 6}(77.8)$ & $11.692^{*}\left(0.001^{*}\right)$ \\
\hline leakage & $19 / 74(57.6)$ & $14 / \mathbf{1 3 6}(42.4)$ & $8.561^{*}\left(0.003^{*}\right)$ \\
\hline Total No. of oocytes & $74 / \mathbf{1 6 6}(35.2)$ & $136 / \mathbf{1 5 4}(64.8)$ & $67.732^{*}\left(<0.001^{*}\right)$ \\
\hline
\end{tabular}

$\chi^{2}$ : Chi square test

p: $\mathrm{p}$ value for comparing between oocytes with $\mathrm{CCs}$ and oocytes without CCs

*: Statistically significant at $\mathrm{p} \leq 0.05$

The effect of CCs on nuclear maturation stages in vitrified / thawed immature buffalo oocytes (Table 8, Fig. 9- 10- 11) showed that, the percentage of oocytes had $1^{\text {st }}$ PB was significantly higher $(\mathrm{P}<0.05)$ in oocytes with CCs group (90.5\%) than oocytes without CCs group $(9.5 \%)$. 
Table 8: The effect of CCs on nuclear maturation of vitrified-thawed immature buffalo oocytes.

\begin{tabular}{|c|c|c|c|c|c|}
\hline & Total & $\begin{array}{c}\text { Oocytes with } \\
\text { CCs } \\
\end{array}$ & $\begin{array}{c}\text { Oocytes } \\
\text { without CCs }\end{array}$ & \multirow[t]{2}{*}{$\chi^{2}$} & \multirow[t]{2}{*}{$\mathbf{p}$} \\
\hline & No. (\%) & No. $(\%)$ & No. $(\%)$ & & \\
\hline Total No. of oocytes & $110(36.4)$ & $92 / \mathbf{1 6 6}(83.6)$ & 18/136 (16.4) & $57.452^{*}$ & $<0.001^{*}$ \\
\hline $\begin{array}{c}\text { Oocytes with } 1^{\text {st }} \text { PB } \\
\text { (MII) }\end{array}$ & $42(38.2)$ & 38/92 (90.5) & $4 / \mathbf{1 8}(9.5)$ & \multirow[t]{2}{*}{2.322} & \multirow[t]{2}{*}{0.128} \\
\hline Oocytes without $1^{\text {st }}$ PB & $68(61.8)$ & $54 / 92(79.4)$ & $14 / 18(20.6)$ & & \\
\hline GV & $18(26.5)$ & $14 / 54(77.8)$ & $4 / 14(22.2)$ & 0.040 & $\begin{array}{c}\mathrm{FE}_{\mathrm{p}}=1.00 \\
0\end{array}$ \\
\hline GVBD & $14(20.6)$ & $12 / 54(85.7)$ & 2/14 (14.3) & 0.428 & 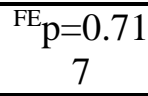 \\
\hline M-I & $11(16.2)$ & $11 / 54(100.0)$ & $0 / \mathbf{1 4}(0.0)$ & 3.402 & $\begin{array}{c}\mathrm{FE}_{\mathrm{p}}=0.10 \\
3\end{array}$ \\
\hline Degenerated & $15(22.1)$ & $9 / 54(60.0)$ & 6/14 (40.0) & 4.436 & $\begin{array}{c}\mathrm{FE}_{\mathrm{p}}=0.06 \\
5\end{array}$ \\
\hline Leakage & $8(11.8)$ & $8 / 54(100.0)$ & $0 / \mathbf{1 4}(0.0)$ & 2.351 & $\begin{array}{c}{ }^{\mathrm{FE}} \mathrm{p}=0.19 \\
1\end{array}$ \\
\hline Parthenogenesis & $2(2.9)$ & $0 / 54(0)$ & 2/14 (100.0) & $7.948^{*}$ & $\begin{array}{c}{ }^{\mathrm{FE}} \mathrm{p}=0.04 \\
0^{*}\end{array}$ \\
\hline
\end{tabular}

\section{$\chi^{2}:$ Chi square test FE: Fisher Exact}

p: $p$ value for comparing between oocytes with CCs and oocytes without CCs.

*: Statistically significant at $\mathrm{p} \leq 0.05$

Oocytes showing $1^{\text {st }} \mathrm{PB}$

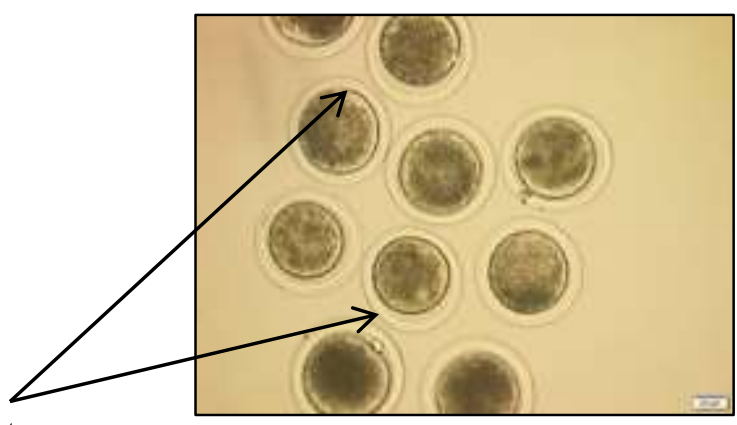

Fig. 9: In vitro matured vitrified / thawed immature buffalo oocytes with cumulus showed $1^{\text {st }} \mathrm{PB}$

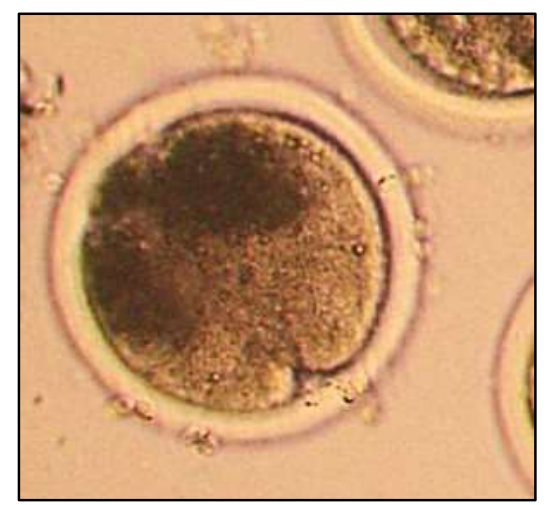

Fig. 10: Parthenogenesis of oocytes appeared after IVM of vitrified-thawed immature buffalo oocytes without CCs (200X). 

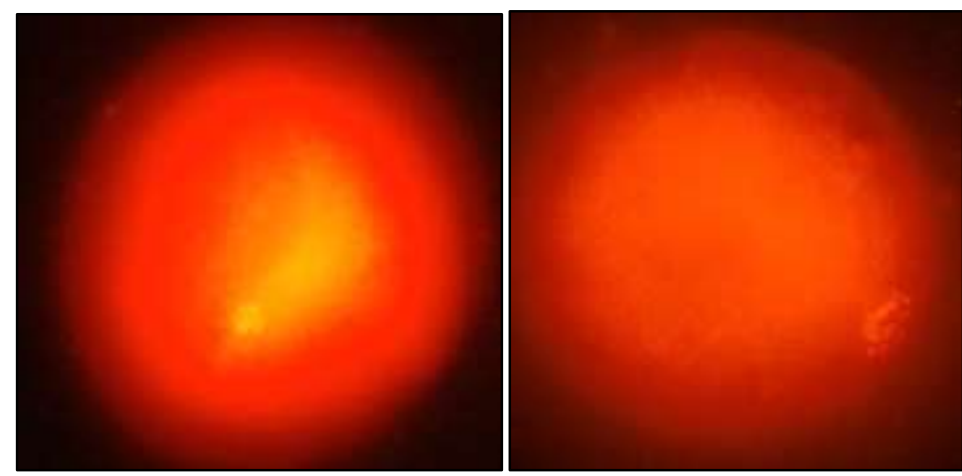

Fig. 11: Oocytes stained by PI showing GV- GVBD (Flourescent microscope 200X)

\section{DISCUSSION}

The first experiment was to study the effect of vitrification and the quality of oocytes (Excellent, Good, Fair and denuded) on the morphology and the meiotic competence of vitrified-thawed immature buffalo oocytes.

In this experiment, there were losses of the No. of oocytes after thawing. Loss of oocytes during the process of freezing and thawing is well documented in several studies, such loss of oocytes occurs owing to sticking of oocytes on the inner wall of straws, adherence to cracks or rough surfaces (sometimes developed during thawing) or oocyte disintegration due to improper vitrification (Isachenko et al., 2005).

In this study, the morphologically abnormal of vitrified-thawed immature buffalo oocytes groups were recorded as cracking in zona pellucida, changes in shape of oocytes and leakage. Similar types of damage have been observed in previous studies (Albarracin et al., 2005; Sharma and Loganathasamy, 2007). Those abnormalities may be due to vitrification of oocytes in $0.25-\mathrm{ml}$ straws causes a delay in heat loss from the solutions, possibly leading to devitrification, i.e. intracellular recrystallization during warming (Morato et al., 2007).

In our results the oocyte quality has a role in the meiotic competence of immature buffalo oocytes either in control or vitrified group. The cytoplasmic and nuclear maturation in control group and vitrified group were significantly higher in excellent and good groups when compared with fair and denuded groups. Moreover, excellent and good quality oocytes of control groups showed significant increase in cytoplasmic and nuclear maturation when compared with vitrified groups. The results in agreement with Bethapudi (2017) revealed that the CCs expansion and nuclear maturation of vitrified /thawed buffalo oocytes ranged from 33-58\% and $8-33 \%$ respectively when compared with control group ( $87.85 \%$ and 66.6 respectively). Dahli et al. (2000) revealed that maturation rate was significantly lower $(31.5 \%)$ in vitrified / thawed immature buffalo oocytes when compared with control group (67\%).

In experiment 2, the recovery rate, normal morphology and nuclear maturation (MII) of vitrified / thawed immature buffalo oocytes with cumulus were significantly higher when compared with oocytes without cumulus. Purohit et al. (2012) revealed that vitrified immature goat oocytes with cumulus were significantly higher than oocytes without cumulus in recovery rate $(86.73$ and $80.31 \%$ respectively), morphology normal rate (94.12 and $89.22 \%$ respectively) and maturation rate (41.25 and $27.48 \%$ respectively), same authors, reported that the cumulus cells attached to oocytes partly offer some protection from cryo-damage due to vitrification. The results were in agreement with Tharasanit et al. (2009) in equine who found that the CCs removal prior to IVM or vitrification have shown a detrimental effect on oocyte morphology and resulted in reduced meiotic competence, MII spindle and chromatin quality for immature vitrified oocytes. Moreover Miyake et al. (1993) found that a compact layer of CCs blocked the permeation of high toxic CPAs and might help prevent swelling of mouse oocytes during removal of the CPAs. 
On the other hand, Horvath and Seidel (2006) partially removed CCs to cryopreserve bovine oocytes and have better results than oocytes with CCs or denuded oocytes. Bogliolo, et al. (2007) reported that immature ovine oocytes vitrified without CCs showed a significantly higher meiotic maturation rate than those with CCs and no differences in spindle and chromatin organization between two groups were observed. It has been reported that the absence of $\mathrm{CCs}$ could provoke a possible shortcoming in protein synthesis and could reflect the levels of molecules involved in the regulation of meiotic and mitotic cell cycles (Combelles et al., 2005). CCs removal increases the MPF activity and accelerates the transition to metaphase stage and the redistribution of cortical granules (Zhou et al., 2010). Parthenogenetic activation was observed in this experiment after IVM of vitrified-thawed immature oocytes without $\mathrm{CCs}$ and that may be due to oocyte vitrification induces spindle disorganization and chromatin fragmentation, as well as parthenogenetic activation (De Blasi et al., 2009). It is still debated as to whether it is necessary to maintain CCs during cryopreservation of immature oocytes, because this need may be species specific (Fujihira et al., 2005; Ruppert-Lingham et al., 2006).

In-conclusion, vitrification affects adversely on the morphology and meiotic competence of immature buffalo oocytes, but excellent and good quality immature vitrified buffalo oocytes with cumulus cells show survivability and maturation rate after thawing.

\section{ACKNOWLEDGEMENTS}

We gratefully acknowledge the financial support of Academy of Science and Technology through the project in title" Assessment the viability of cryopreserved buffalo embryo and semen" and this work was done in embryo and genetic resource conservation bank in national research center, financially supported from STDF (CB grant ID 2339).

\section{REFERENCES}

Albarracin, J.L.; Morato, R.; Izquirerdo, D. and Mogas, T. (2005): Vitrification of calf oocytes: effects of maturation stage and prematuration treatment on the nuclear and cytoskeletal components of oocytes and their subsequent development. Molecular and Reproduction Development, 72: 239-249.

Bethapudi, S. (2017): Effect of cryopreservation on in vitro maturation and in vitro fertilization of buffalo oocytes. (PhD in Gynaecology and Obstetrics), College of Veterinary Science, P.V Narsimha Rao Telangana Veterinary University, India.

Bogliolo, L.; Ariu, F.; Fois, S.; Rosati, I., Zedda, M.T.; Leoni, G. and Ledda, S. (2007): Morphological and biochemical analysis of immature ovine oocytes vitrified with or without cumulus cells. Theriogenology, 68(8): 1138-1149.

Chian, R.C.; Park, C.K. and Sirard, M.A. (1996): Cumulus cells act as a sperm trap during in vitro fertilization of bovine oocytes. Theriogenology, 45:258.

Combelles, C.M.; Fissore, R.A.; Albertini, D.F. and Racowsky, C. (2005): In vitro maturation of human oocytes and cumulus cells using a co-culture three-dimensional collagen gel system. Human Reproduction, 20(5): 1349-1358.

De Blasi, M.; Mariotti, E.; Rubessa, M.; Di Francesco, S.; Campanile, G.; Zicarelli, L. and Gasparrini, $B$. (2009): Exposure to ethylene glycol (EG) and dimethylsulfoxide (DMSO) causes activation and spindle anomalies in buffalo (Bubalus bubalis) oocytes. Reproduction, Fertility and Development, 21: 131.

De Wit, A.A.C.; Wurth, Y.A. and Kruip, T.A.M. (2000): Effect of ovarian phase and follicle quality on 
morphology and developmental capacity of the bovine cumulusoocyte complex. Journal of Animal Science, 144: 1277-1283.

Dhali, A.; Manik, R.S.; Das, S.K.; Singla, S.K. and Palta, P. (2000): Vitrification of buffalo (Bubalus bubalis) oocytes. Theriogenology, 53: 1295-1303.

Escribano, O.N.; Smits, K.; Piepers, S.; Van den Abbeel, E.; Woelders, H. and Van Soom, A. (2016): Role of cumulus cells during vitrification and fertilization of mature bovine oocytes: effects on survival, fertilization, and blastocyst development. Theriogenology, 86: 635-41

Fujihira, T.; Nagai, H. and Fukui, $Y$. (2005): Relation 6 ship between equilibration times and the presence of cumulus cells, and effect of taxol treatment for vitrification of in vitro matured porcine oocytes. Cryobiology, 51(3): 339-343.

Gautam, S.K.; Verma, V.; Palta, P.; Chauhan, M.S. and Manik, R.S. (2008): Effect of type of cryoprotectant on morphology and developmental competence of in vitro-matured buffalo (Bubalus bubalis) oocytes subjected to slow freezing or vitrification. Reproduction and Fertility Development, 20:490-6.

Horvath, G. and Seidel JR, G.E. (2006): Vitrification of bovine oocytes after treatment with cholesterol-loaded methyl-b-cyclodextrin.

Theriogenology, 66: 1026-1033.

Isachenko, V.; Montag, M.; Isachenko, E.; Zaeva, V.; Krivokharchenko, I. and et al. (2005): Aseptic technology of vitrification of human pronuclear oocytes using open-pulled straws. Human Reproduction, 20: 492-96.

Iscove, N.N.; Guilbert, L.J. and Weyman, C. (1980): Complete Replacement of Serum in Primary Cultures of Erythropoietin Dependent Red Cell Precursers [CFU-E] by Albumin, Transferrin, Iron, Unsaturated Fatty
Acid, Lecithin and Cholesterol. Experimental Cell Research, 126: 121-126.

Ju, J.C.; Parks, J.E. and Yang, X. (1999): Thermotolerance of IVM-derived bovine oocytes and embryos after short term heat stress. Molecular, Reproduction and Developelopment, 53: 336-340.

Kandil, O.M.; Abdoon, A.S.S.; Murakami, M.; Otoi, T. and Suzuki, T. (1999): New technique, using a portable $\mathrm{CO} 2$ incubator, for the production of in vitro fertilized Egyptian buffalo embryos. Journal of Reproduction Development, 45: 315-320.

Miyake, T.; Kasai, M.; Zhu, S.F.; Sakurai, T. and Machida, T. (1993): Vitrification of mouse oocytes and embryos at various stages of development in an ethylene glycol based solution by a simple method. Theriogenology, 40: 121-134

Morato, R.; Izquierdo, D.; Paramio, M.T. and Mogas, T. (2008): Cryotops versus open-pulled straws (OPS) as carriers for the cryopreservation of bovine oocytes: effects on spindle and chromosome configuration and embryo development. Cryobiology, 57: 137-141.

Nandi, S.; Raghu, H.; Ravindranatha, B. and Chauhan, M. (2002): Production of buffalo (Bubalus bubalis) embryos in vitro: premises and promises. Reproduction in Domestic Animals, 37: 65-74.

Purohit, G.N.; Meena, H. and Solanki, K. (2012): Effects of vitrification on immature and in vitro matured, denuded and cumulus compact goat oocytes and their subsequent fertilization. Journal of Reproduction and Infertility, 13(1): 53-59.

Ruppert-Lingham, C.J.; Paynter, S.J.; Godfrey, J.; Fuller, B.J. and Shaw, R.W. (2006): Membrane integrity and development of immature murine cumulus-oocyte complexes following slow cooling to $-60{ }^{\circ} \mathrm{C}$ : the effect of 
immediate re-warming, plunging into LN2 and two-controlled-rate-stage cooling. Cryobiology, 52: 219-227.

Sharma, G.T. and Loganathasamy, K. (2007): Effect of meiotic stages during in vitro maturation on the survival of vitrified-warmed buffalo oocytes. Veterinary Research Communication, 31(7):881-93.

Sianturi, R.G.; Thein, M.; Wahed, H. and Rosnina, Y. (2002): Effect of collection technique on yield of bovine oocytes and the development potential of oocytes from different grades of oocytes. Indonesian Journal of Animal and Veterinary Sciences 7(3): 188-193.

Somfai, T.; Kikuchi, K. and Nagai, T. (2012): $\quad$ Factors affecting cryopreservation of porcine oocytes. Journal of Reproduction Development, 58: 17-24.

Szurek, E.A. and Eroglu, A. (2011): Comparison and avoidance of toxicity of penetrating cryoprotectants. PloS one 6: e27604

Tharasanit, T.; Colleoni, S.; Galli, C.; Colenbrander, B. and Stout, T.A.E. (2009): Protective effects of the cumulus-corona radiata complex during vitrification of horse oocytes. Reproduction, 137: 391-401.

Wani, N.; Misra, A. and Maurya, S. (2004): Maturation rates of vitrified-thawed immature buffalo (Bubalus bubalis) oocytes: effect of different types of cryoprotectants.

Animal

Reproduction Science, 84: 327-35.

Zhang, L.; Jiang, S.; Wozniak, P.J.; Yang, X. and Godke, R.A. (1995): Cumulus cell function during bovine oocyte maturation, fertilization and embryo development in vitro. Molecular, Reproduction and Development, 40: $338-344$.

Zhou, X.L.; Al Naib, A.; Sun, D.W. and Lonergan, P. (2010): Bovine oocyte vitrification using the cryotop method: Effect of cumulus cells and vitrification protocol on survival and subsequent development. Cryobiology, 6: 66-72.

Zoheir, K.M.; Abdoon, A.; Mahrous, K.; Amer, M.; Yang, Z.M.L. and ElNahass, E. (2007): Effects of season on the quality and in vitro maturation rate of Egyptian buffalo (Bubalus bubalis) oocytes. Journal of Cell and Animal Biology, 1: 029-33.

\section{تأثير جودة البويضات والخلايا التزاكية للبويضة علي الاتقسام الميوزي لبويضات الجاموس المجمدة تجميا فائق السرعة الآلمات}

\section{سامية محمد عبد الرحيم ، أمبية محد قنديل ، إيمان السبي البواب ، كمال كمال متولي ، أحمد عبلون}

E-mail: omaima_mk@yahoo.com Assiut University web-site: www.aun.edu.eg

تم تصميم هذه التجربة لدراسة تأثثر جودة البويضات ووجود الخلايا التاكمية علي القدرة علي الانقسام الميوزي لبويضات التيات

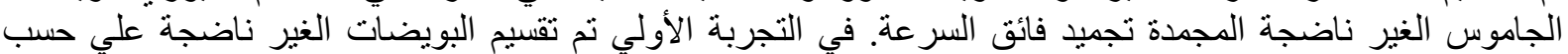

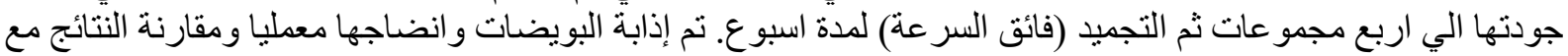

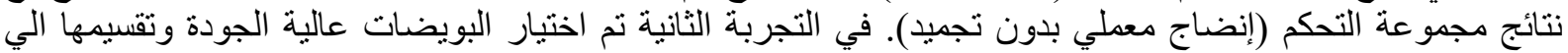

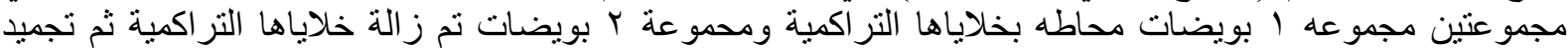

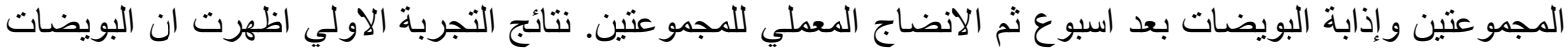

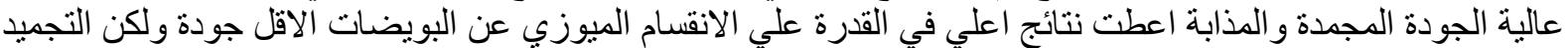

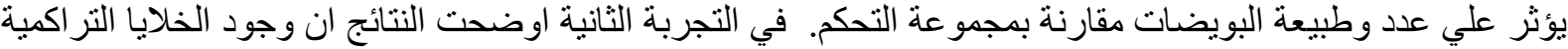

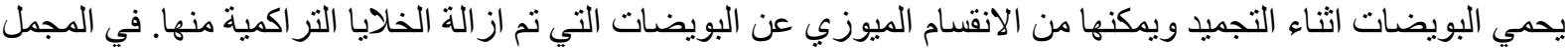

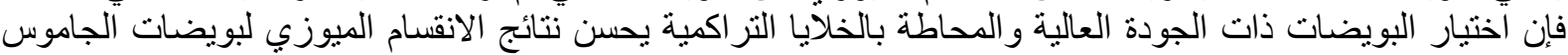
الغير ناضجة و المجمدة تجميد فائق السرعة. 